\title{
Fjenden fra Nord
}

\section{Nedslag i den skandinaviske gammeltestamentlige forskning i første halvdel af 1900-tallet}

\author{
Professor, dr.theol. \\ Jesper Hogenhaven, Kobenhavns Universitet
}

\begin{abstract}
The years 1900-1950 were a fruitful and productive period in Old Testament research in the Nordic countries. Represented by internationally renowned figures like Johannes Pedersen, Sigmund Mowinckel, and Ivan Engnell, Scandinavian Old Testament scholarship gained an independent profile over against the German and Anglo-Saxon realms. This article explores themes of central importance to Nordic scholars in this period, and attempts to spell out some of the more significant nuances and differences among them. Finally, I raise the question to which extent we can meaningfully speak of tendencies and features common to Scandinavian Old Testament scholars 1900-1950, and whether such tendencies reflect more general cultural trends of their time. I tentatively point to some common denominators: A comparative approach that takes seriously the ancient Near Eastern context of the Old Testament texts, a marked emphasis on cultic perspectives, and an interest in the role played by orality in the formation of Old Testament literary genres and texts. Despite some very different accents put by various scholars, these points may be described as characteristic of Scandinavian scholarship in the period.
\end{abstract}

Keywords: Old Testament - History of Scholarship - Nordic countries - Cult - Sacred Kingship - Tradition History - Johannes Pedersen Sigmund Mowinckel - Ivan Engnell - Johannes Lindblom.

Første halvdel af det tyvende århundrede er en særdeles frugtbar periode for den gammeltestamentlige forskning i de nordiske lande. Den skandinaviske gammeltestamentlige forskning får i denne periode i høj grad sin egen selvstændige profil i forhold til, hvad der i det samme tidsrum foregår på det europæiske kontinent og i den angelsaksiske verden. ${ }^{1}$ I det følgende er det meningen at se på nogle

1. Douglas A. Knight, "Old and new in Scandinavian interpretation of the Hebrew Bible", History, Archaeology and The Bible Forty Years After "Historicity", red. Ingrid Hjelm \& Thomas L. Thompson, Changing Perspectives 6 (London/ New York: Routledge 2016), 17-34. Se også Antti Laato, "Biblical Scholarship in Northern Europe", Hebrew Bible/Old Testament, The History of Its Interpretation III. From Modernism to Post-Modernism (The Nineteenth and Twentieth Centuries). Part 2: The Twentieth Century: A Century of Modernism and Historicism, red. Magne 
markante nedslag i skandinavisk forskning 1900-1950. Med afsæt heri vil jeg undersøge, om og i givet fald hvordan man kan tale om, at de markante skandinaviske bidrag til udforskningen af Det Gamle Testamente er båret af bestemte fælles grundtræk. Endvidere skal det spørgsmål stilles, om eventuelle fælles træk kan sættes i forbindelse med mere generelle historiske og kulturelle forudsætninger, som kendetegner perioden.

"Fjenden fra Nord" ("Der Feind vom Norden") skal have været den norske gammeltestamentler Sigmund Mowinckels (1884-1965) øgenavn blandt tyske kolleger i den senere del af hans karriere. I sine yngre forskerdage skal han derimod i Tyskland være blevet omtalt som "lyset fra Nord" ("Das Licht vom Norden"). ${ }^{2}$ Det er uvist, hvor meget hold der er i dette lille stykke tradition; men anekdoten siger noget om den fornemmelse af en modsætning imellem tysk og skandinavisk forskning, som eksisterede i dele af de gammeltestamentlige fagmiljøer. ${ }^{3}$

\section{Baggrund: Tendenser i forskningen uden for Skandinavien}

En række arkæologiske udgravninger og undersøgelser i den nærorientalske verden bidrog i løbet af første halvdel af 1900-tallet til at udvide forstålsen af de gammeltestamentlige tekster og deres verden. Perioden oplevede i særdeleshed to betydningsfulde tekstfund: Ras Shamra, oldtidens Ugarit, hvis righoldige arkiv blev fremdraget 19291936, og håndskrifterne fra Qumran, der kom for dagen 1947-1952. Begge fund fik stor betydning for arbejdet med Det Gamle Testamente.

Noget tilsvarende kan siges om inddragelsen af metoder og synspunkter fra de samtidige humanvidenskaber. Inden for den gammel-

Sæbø (Göttingen: Vandenhoeck \& Ruprecht 2014), 336-370. Om receptionen af Det Gamle Testamente i Danmark ca. 1920-1940 se Jesper Høgenhaven, "Mellem tradition og nybrud. Det Gamle Testamente mellem to verdenskrige", Dansk kirke og kultur $i$ mellemkrigstiden, red. Rasmus Markussen m.f., Publikationer fra Det Teologiske Fakultet 68 (København: Det Teologiske Fakultet 2016), 75-93.

2. Jf. Rudolf Smend, "Licht vom Norden. Mowinckel und Deutschland", Studia Theologica 53 (1999), 79-96 (79); [= Rudolf Smend, Bibel und Wissenschaft. Historische Aufsätze (Tübingen: Mohr Siebeck 2004), 159-173]; Niels Astrup Dahl, "Sigmund Mowinckel: Historian of Religion and Theologian", SJOT 2 (1988), 8-22 (8). Se også Sigurd Hjelde, Sigmund Mowinckel und siene Zeit: Leben und Werk eines norwegischen Alttestamentlers, FAT 50 (Tübingen: Mohr Siebeck 2006).

3. Betegnelsen "fjenden fra Nord" spiller selvsagt på motivet med den ukendte ulykkebringer nordfra, som møder os i de indledende kapitler af Jeremias' Bog: "Fra nord skal ulykken slippes løs over alle landets indbyggere” (Jer 1,14). 
testamentlige eksegese var tiden efter Første Verdenskrig således præget af en række nye tendenser inden for form- og traditionshistorien. I Tyskland, der stadig var førende på bibelforskningens felt, var det især Albrecht Alts, Martin Noths og Gerhard von Rads arbejder, der banede nye veje. Alt forsøgte at udnytte periodens antropologiske beskrivelser af forholdet imellem Mellemøstens nomader og fastboende folk som nøgle til forståelsen af israelitternes indvandring i Kana'an: Ifølge Alt kunne indvandringen tolkes som en gradvis proces, hvor småkvægsnomader fra kulturlandets randområder slog sig ned som agerbrugere i konkurrence med landets hidtidige befolkning. ${ }^{4}$ Noth gjorde gældende, at traditionen om Israels tolv stammer afspejlede det tidlige Israels organisation som et "amfiktyoni", dvs. et sakralt stammeforbund med en central helligdom. ${ }^{5}$ Von Rad argumenterede for, at strukturen i Mosebøgernes og Josvabogens fortælling om israelitternes udfrielse fra Egypten, ørkenvandring og erobring af Kana'an kunne føres tilbage til en kultisk genfortælling af forløbet, som genfindes i 5 Mos 26,5-9 (ganske vist i redigeret skikkelse). ${ }^{6}$

Samtidig med denne nyorientering på det specifikt faglige område finder der i Tyskland i tiden efter Første Verdenskrig også en teologisk genbesindelse på Det Gamle Testamentes betydning og relevans for kristen teologi og forkyndelse sted. ${ }^{7}$ Baggrunden for denne vending i retning af at betone Det Gamle Testamentes plads og betydning i den kristne kirkes kanon er den forudgånde periodes overvejende religionshistorisk orienterede grundforståelse af de gammeltestamentlige tekster. ${ }^{8}$

4. Albrecht Alt, Die Landnahme der Israeliten in Palästina, Reformationsprogramm der Universität Leipzig 1925 [= Albrecht Alt, Kleine Schriften zur Geschichte des Volkes Israel I (München: C.H. Beck'sche Verlagsbuchhandlung 1953), 89-125]; "Erwägungen über die Landnahme der Israeliten in Palästina", Palästinajahrbuch des Deutschen evangelischen Instituts für Altertumswissenschaft des Heiligen Landes zu Jerusalem 35 (1939), 8-63 [= Albrecht Alt, Kleine Schriften I, 126-175].

5. Martin Noth, Das System der zwölf Stämme Israels, BWANT 52 (Stuttgart: W. Kohlhammer 1930).

6. Gerhard von Rad, Das formgeschichtliche Problem des Hexateuchs, BWANT 78 (Stuttgart: W. Kohlhammer 1938).

7. Tydelige vidnesbyrd om denne nyorientering er Walther Eichrodt, Theologie des Alten Testaments I-III (Leipzig: J. C. Hinrichs Verlag 1933-1939); Otto Procksch, Theologie des Alten Testaments (Gütersloh: C. Bertelsmann 1950); Gerhard von Rad, Theologie des Alten Testaments. I. Die Theologie der geschichtlichen Überlieferungen Israels (München. Chr. Kaiser: 1957); II. Die Theologie der prophetischen Überlieferungen Israels (München: Chr Kaiser 1960). Jævnfør også den noget tendentiøse fremstilling i Hans-Joachim Kraus, Geschichte der historisch-kritischen Erforschung des Alten Testaments, 4. Aufl. (Neukirchen-Vluyn: Neukirchner Verlag 1988), 421434.

8. Forsøgene på en teologisk "tilbageerobring” af Det Gamle Testamente forstærkedes givetvis yderligere i løbet af 1930rne under indtryk af nazi-regimets og de "ty- 
Den gammeltestamentlige eksegese i Skandinavien i slutningen af 1800-tallet og begyndelsen af 1900-tallet

I løbet af de sidste årtier af 1800-tallet havde de ledende gammeltestamentlige eksegeter $\mathrm{i}$ de skandinaviske lande orienteret sig $\mathrm{i}$ retning af den historisk-kritiske bibelvidenskab, som den især blev praktiseret i Tyskland. ${ }^{9}$ For Det Gamle Testamentes vedkommende betød denne orientering først og fremmest, at man accepterede den tese om Mosebøgernes gradvise tilblivelse, som især Julius Wellhausen havde slået til lyd for: Mosebøgerne var, mente man, redigeret sammen af fire oprindeligt af hinanden uafhængige "kildeskrifter" Jahvisten, Elohisten, Deuteronomikeren og Præsteskriftet. Sammen med kildesondringen og den fordeling af de enkelte kilder på forskellige perioder, som Wellhausen-skolen var nået frem til, antog man en bestemt rekonstruktion af den israelitisk-jødiske religions historiske udvikling: Fra en primitiv begyndelse som "stammereligion" eller "folkereligion" havde det gamle Israels religiøse forestillingsverden gennemløbet en række transformationer. Det absolutte højdepunkt var de store profeters etiske monoteisme. Disse geniale personligheder og forkyndere var nået frem til en hidtil ukendt indsigt i Guds transcendente natur og ubetingede etiske fordring til mennesker; og det var på dette grundlag, de måtte proklamere Jahves dom over sit skyldige folk. Den store skillelinje i Israels historie og religionshistorie var det babyloniske eksil, som i de overlevendes øjne måtte virke som en endegyldig stadfæstelse af profeternes dom. I tiden under og efter eksilet satte en ny fase imidlertid ind, bestemt af forsøgene på at sikre sig mod en gentagelse af katastrofen gennem lydighed mod Jahves vilje. Dette program gav sig konkret udslag i udviklingen af en religionstype koncentreret om rigid observans i forhold til Moselovens bestemmelser. Fremkomsten af den eftereksilske jødiske lovfromhed blev således opfattet som en nedadgående linje med farisæismen som den naturlige kulmination.

Kildehypotesen med dens historiske forudsætninger og implikationer var i tiden omkring 1900 kommer til at stå som noget nær indbegrebet af historisk-kritisk bibelvidenskab. I Danmark var denne udgave af den historisk-kritiske eksegese repræsenteret af Frants Buhl (1850-1932),

ske kristnes” udtrykkelige angreb på og afvisning af den gammeltestamentlige arv. 9. For en forskningshistorisk oversigt over denne periode se Jesper Høgenhaven, "Biblical Scholarship in Northern Europe", Hebrew Bible/Old Testament, The History of Its Interpretation III. From Modernism to Post-Modernism (The Nineteenth and Twentieth Centuries). Part 1: The Nineteenth Century: A Century of Modernism and Historicism, red. Magne Sæbø (Göttingen: Vandenhoeck \& Ruprecht 2013), 223-243. 
der var professor i Det Gamle Testamente i København 1882-1890 og i semitisk filologi 1898-1922. ${ }^{10}$ Frants Buhls efterfølger i det gammeltestamentlige professorat I. C. Jacobsen (1862-1948), professor 18911929, fortsatte Buhls linje med kildesondringen og den dermed sammenhængende kritiske rekonstruktion som udgangspunkt for forståelsen af Det Gamle Testamente. En tilsvarende position indtog i samme periode kollegerne Simon Michelet (1863-1942, professor 1896-1933) i Kristiania og Erik Stave (1857-1932, professor 1899-1922) i Uppsala.

Begyndelsen af 1900-tallet var således kendetegnet ved en forholdsvis høj grad af konsensus blandt de ledende forskere om, hvordan den gammeltestamentlige litteratur måtte være blevet til, og om den religionshistorie, som teksterne afspejlede. Den historisk-kritiske bibeleksegese var med den generation, der nu beklædte lærestolene ved de nordiske universiteter, slået endegyldigt igennem; og man byggede over hele linjen videre på især den tyske forsknings resultater, som man anså for det solide, uomgængelige grundlag for det fortsatte arbejde med teksterne. I sin fremstilling af dansk teologis historie tegner N. H. Søe et lidt nedslående billede af den gammeltestamentlige forsknings situation i perioden efter kildekritikkens sejrsgang. Med særligt henblik på I.C. Jacobsen, der beskrives som Buhls trofaste og lidt uselvstændige efterfølger i København, skriver han:

Blot nogenlunde bemærkelsesværdige nye synsmåder var der ikke plads for. Det var, som var de gltst. problemer væsentlig set løst, så kun petitesser stod tilbage ... Mens faget i 1890erne vel lå forrest i vågne teologers interessesfære, var det efterhånden blevet et emneområde, som man snarest måtte fraråde de unge at kaste sig over. Der var ikke megen grøde at forvente. ${ }^{11}$

Fra omkring 1920 sætter en nyorientering imidlertid ind i de skandinaviske lande, hvad angår arbejdet med Det Gamle Testamente. Der er tale om en række af hinanden uafhængige indsatser i flere lande og på forskellige planer; og samtidig er der tale om en ny uafhængighed i forhold til den tyske forskningstradition.

10. Se Jesper Høgenhaven, "Frants Buhl som gammeltestamentlig teolog", DTT 78/3 (2015), 202-224.

11. N. H. Søe, Dansk teologi siden 1900, Kirkehistoriske studier, 11. række nr. 21 (København: Gad 1965), 89. 
Johannes Pedersen og det israelitiske menneske- og verdenssyn

På dansk grund er det i første række Johannes Pedersens arbejder, ganske særligt hans firebindsværk Israel I-IV, der udkom fra 1920 til 1934, som i denne periode står for noget væsentligt nyt. ${ }^{12}$ Johannes Pedersen (1883-1977), der i 1912 blev dr.phil. på en afhandling om eden hos de semitiske folk, ${ }^{13}$ blev i 1916 docent i Det Gamle Testamente og overtog fra 1922 Frants Buhls professorat i semitisk filologi.

Israel I-IV er et inciterende forsøg på at finde ind til den inderste kerne i de gammeltestamentlige teksters univers. Centralt i de gamle israelitters livsopfattelse står ifølge Pedersens inciterende fremstilling deres begreb om "sjælen". Når israelitterne forstår mennesket som en

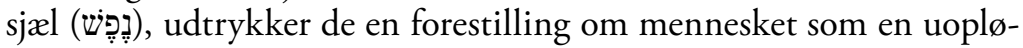
selig helhed med sit bestemte særpræg. Sjælen er "først og fremmest en Helhed med et ejendommeligt Præg" (Pedersen 1920, 76). Den israelitiske forståelse af mennesket som sjæl indebærer lige præcis ikke nogen opdeling af mennesket i materielt og åndeligt, men ser det som en helhed, hvori alle fysiske og psykiske egenskaber indgår. Israelit-

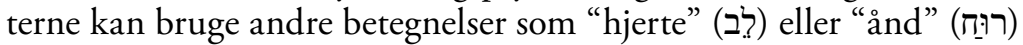
men de opfatter til alle tider sjælen som en helhed præget af vilje og virke. Sjælen tenderer ifølge Pedersen for de gamle israelitter altid i retning af handling - sjælens karakteristiske egenskaber viser sig i lige så høj grad i en persons enkelte legemlige og mentale udtryk som i personens tanker, planer og handlinger. Sjælen er "levende", fyldt med livskraft; og sjæl og liv er forestillinger, der ligger tæt op ad hinanden: "Sjælen er det særprægede, formede Liv, Livet er den i Sjælen formede Kraft og Ejendommelighed" (Pedersen 1920, 119). Den israelitiske forestilling om det gode er centreret om den gode, sunde, stærke og sammenhængende sjæl. Den livskraft, som sjælen ikke kan undvære, og som skaber lykke og fremgang, er hvad israelitterne kalder velsignelsen. Hvor der er velsignelse, er der også fred, idet den enkelte sjæl indgår i et harmonisk fællesskab af sjæle. Det basale naturlige fællesskab er slægten; det forpligtende fællesskab udmønter sig endvidere i pagten, der netop betegner det sjælelige fællesskab. I

12. Johannes Pedersen, Israel. I-II. Sjaleliv og Samfundsliv (København: Branner og Korch 1920); III-IV. Hellighed og Guddommelighed (København: Branner og Korch 1934). Pedersens værk udkom i engelsk oversættelse som Israel: Its Life and Culture 1-4 (Oxford: OUP 1926-1940).

13. Johannes Pedersen, Den semitiske Ed og beslagtede Begreber samt Edens Stilling i Islam (København: V. Pios Boghandel (Povl Branner) 1912). Udvidet tysk oversættelse: Der Eid bei den Semiten in seinem Verhältnis zu verwandten Erscheinungen sowie die Stellung des Eides im Islam, Studien zur Geschichte und Kultur des islamischen Orients. Zwanglose Beihefte zu der Zeitschrift "Der Islam” (Strassburg: Karl J. Trübner 1914). 
modsætning hertil står synd og forbandelse, der er udtryk for en splittelse i sjælen eller en opløsning af det, der er bestemt til at være en sammenhængende helhed. De gammeltestamentlige tekster præsenterer således sine læsere for et storslået sammenhængende verdenssyn, hvor sjælenes fællesskab som udtryk for liv, fred og velsignelse står over for kaos i form af død, opløsning, løgn og tomhed.

På baggrund af dette gennemførte helhedssyn på israelitisk kultur går Pedersen kritisk til litterærkritikken og dens fokus på kildesondring og datering. Den historisk-kritiske forskning har ret i, at de gammeltestamentlige tekster i deres slutform bærer præg af mange forskellige tiders indflydelse; men de for forskellige tiders bidrag kan netop ikke skilles fra hinanden som isolerede lag. Fx unddrager de kultiske og sociale love i Mosebøgerne sig en præcis datering. Denne type bestemmelser bevarer nemlig det samme grundpræg ned gennem århundrederne, men er samtidig under konstant omformning, hvad detaljerne angår. Noget tilsvarende gælder fortællingerne, der kombinerer meget gammelt stof og langt senere konstruktioner. I Pedersens øjne har både lovsamlingerne og fortællingerne formentlig først i den eftereksilske tid fået deres endegyldige litterære udformning; men de rummer også langt ældre traditioner, hvoraf noget er bevaret og gengivet med stor troskab, medens andet er omformet efter en senere tids formål og behov. Opdeling i kilder og opstilling af en kronologisk rækkefølge er derfor uden den helt store interesse, når det drejer sig om at forstå teksternes indre sammenhæng og betydning (Pedersen 1920, 18-23).

Pedersens Israel I-IV har i udgangspunktet ikke nogen teologisk dagsorden, men er båret af ønsket om at forstå den antikke nærorientalske kultur, som skrifterne udspringer af, med så stor en dybde og indlevelse som muligt. Pedersens forrygende velskrevne fremstilling kom dog til at sætte sit præg på teologernes forhold til Det Gamle Testamente gennem lang tid. Det er meget tydeligt, at Israel I-IV er inspireret af Vilhelm Grønbechs forfatterskab og især hans beskrivelse af de gamle nordboers menneske- og verdenssyn - en inspiration, som Pedersen da også udtrykkeligt vedkender sig. ${ }^{14}$

14. Israel I-IV er tilegnet Vilhelm Grønbech “i Venskab”. Det skal til gengæld ifølge god overlevering have irriteret Pedersen en del, at han ofte blev fremstillet som "elev" af Vilhelm Grønbech. I virkeligheden var der efter alt at dømme først og fremmest tale om gensidig inspiration og faglig udveksling imellem kolleger med forskellige arbejdsområder men med en fælles tilgang til det religionshistoriske stof. Om Pedersens forhold til Grønbech se Bo Alkjær, "Forskning og kammeratskab. Johannes Pedersen og religionshistorikerne", Den sammenklappelige tid. Festskrift til Jørgen Podemann Sørensen, red. Tim Jensen \& Mikael Rothstein (København: Forlaget Chaos 2011), 13-26. 
Pedersen leverede en opsummerende redegørelse for sin forståelse af Det Gamle Testamente i en artikel fra 1931. ${ }^{15}$ Her lægger han klart afstand til Wellhausen og litterærkritikken, som han mener bygger på et dybt problematisk - og udtalt moderne europæisk - evolutionistisk historiesyn (Pedersen 1931, 160). I denne evolutionistiske optik bliver det gammeltestamentlige Israel en kultur, der bevæger sig fra det nederste til det højeste trin i udviklingen og dermed får en slags eksemplarisk eller paradigmatisk status. Denne betragtning bliver dog kun mulig, fordi man vilkårligt fremhæver de træk, "som bedst kan tydes i overensstemmelse med det moderne protestantiske Europas synsmaade, nemlig profeternes forkyndelse" (Pedersen, ibid.). Pedersen vil gribe bag om rationalismens og oplysningstidens syn på Det Gamle Testamente og på det gamle Israel som idealfolket, et syn, som han mener, at Wellhausen i bund og grund viderefører. I stedet ønsker Pedersen at fortsætte linjen fra Herder, hvis ideal er indlevelsen i det enkelte folks sjælelige karakter og forudsætninger: Israel må i denne forstand forstås indefra som en kultur i sin egen ret (Pedersen 1931, 142-143).

Det er tankevækkende, at Pedersen udtrykkeligt griber tilbage til Herders forståelse af det gammeltestamentlige poetiske univers. Hans indflydelsesrige fremstilling af de gamle israelitters anskuelse af verden rummer et umiskendeligt præg af romantisering. Pedersens grundindstilling er da også længe blevet betragtet som metodisk forældet; bl.a. har forestillingen om, at sprogets grammatiske strukturer direkte afspejler den bagvedliggende særlige mentalitet eller psykologi ikke været i høj kurs gennem de seneste menneskealdre. ${ }^{16}$ Men i sin tid var der utvivlsomt noget både befriende og dragende ved Pedersens inciterende fremstilling af det fremmedartede univers i Det Gamle Testamente. Hans fremstilling var i mange år det nærmeste, man kom en gammeltestamentlig teologi på dansk; og paradoksalt nok bidrog understregningen af det eksotiske element ved teksterne sikkert til at gøre dem attraktive og relevante i samtidens forståelse.

\section{Sigmund Mowinckel og den israelitiske kult}

Sigmund Mowinckel - der efter studier hos bl.a. Hermann Gunkel - i 1917 blev docent og fra 1922 professor i Det Gamle Testamente i

15. Johannes Pedersen, "Opfattelsen af det gamle testamente", Norsk Teologisk Tidsskrift 32 (1931), 137-162. Pedersens artikel blev også trykt på tysk: "Die Auffasung vom Alten Testament", ZAW 49 (1931), 161-181.

16. Pedersens grundsyn prægede også hans hebraiske grammatik fra 1926, der kom til at tjene som lærebog i flere generationer. 
Oslo, er givetvis den nordiske gammeltestamentlige ekseget, der har $ø$ vet størst indflydelse uden for sit eget land. Hans Psalmenstudien $I-V I$, der udkom i årene 1921-1924, var med til at sætte dagsordenen for en hel generation af salmeforskere. Mowinckel gennemfører her konsekvent en kultisk orienteret tolkning. Gunkel havde peget på en forbindelse imellem salmernes litterære form og kultiske handlinger og situationer, men antog, at salmerne var litterære imitationer af de oprindelige kultiske tekster. Mowinckel forankrer salmelitteraturen direkte i kulten: Når salmisten i de individuelle klagesalmer henviser til sygdom og ulykker, der har ramt ham, og anråber Jahve om befrielse fra sine fjender, afspejler det en forestilling om, at fjenderne ved deres onde trolddomsmagt (אָ har håført salmisten hans lidelser. ${ }^{17}$ Disse salmer skal ligesom de babyloniske klagesalmer forstås konkret som kultiske tekster. Det typiske "jeg”, der taler, repræsenterer den israelit, der søger renselse og oprejsning i Jahves helligdom.

I tredje bind af Psalmenstudien udkaster Mowinckel sin hypotese om Jahves tronbestigelsesfest. ${ }^{18}$ Hans afsæt er en række gammeltestamentlige salmer, der tematiserer Jahves kongemagt, særlig "tronbestigelsessalmerne" (S1 47; 93; 95-100). Med udgangspunkt i Sl 47,6 bestemmer Mowinckel disse salmers hjemsted som en kultisk begivenhed, hvor Jahves ark bæres i procession for at blive genindsat på sin plads i templet som et konkret udtryk for, at Jahve genindtager sin plads på tronen. Jahves tronbestigelse må ifølge Mowinckel være blevet fejret i kongetidens Jerusalem som en årligt tilbagevendende nytårsfest i analogi med den babyloniske akitu-fest. Tronbestigelsesfesten, som er det oprindelige indhold i efterårets festkompleks (der senere bliver til nytårsfest, løvhyttefest og forsoningsdag) har som tema genoprettelsen af den skabte verdensorden, nedkæmpelsen af kaosmagterne, dommen over fjenderne og redningen af Jahves folk. På et tidspunkt er den gammeltestamentlige eskatologi vokset ud af tronbestigelsesfestens motivkreds som en sekundær projektion ud i fremtiden af festens centrale motiver.

Mowinckel ser også en oprindelig forbindelse imellem kult og profeti. En række salmetekster afspejler nemlig også et profetisk element i kulten, som Mowinckel mener har været hjemsted for en institu-

17. Mowinckel, Psalmenstudien I. Åän und die individuellen Klagepsalmen Videnskabsselskapets Skrifter. II. Hist.-filos. Klasse 1921. No. 4 (Kristiania: In Kommission bei Jacob Dybwad 1921).

18. Mowinckel, Psalmenstudien II. Das Thronbesteigungsfest Jahwäs und der Ursprung der Eschatologie, Videnskabsselskapets Skrifter. II. Hist.-filos. Klasse 1921. No. 6 (Kristiania: In Kommision bei Jacob Dybwad 1922). Et tidligere studie til emnet (men uden det eskatologiske perspektiv) er Mowinckel, "Tronstigningssalmerne og Jahves tronstigningsfest", Norsk teologi til reformationsjubileet. Specialhefte til NTT (1917), 13-79. 
tionelt forankret kultprofeti. ${ }^{19}$ Der bliver således ikke tale om nogen diametral modsætning imellem profetisk religion og kultreligion som ofte antaget i den æld re gammeltestamentlige forskning.

Også for andre dele af den gammeltestamentlige forskning var Mowinckels arbejde banebrydende: I sin bog fra 1927 om de ti bud forsøgte han at knytte beskrivelsen af Jahves pagt med Israel på Sinaj til en kultisk tradition. ${ }^{20}$ Stor indflydelse fik også Mowinckels arbejde med Esajasbogens komposition. ${ }^{21}$ Blandt hans talrige bidrag til den gammeltestamentlige eksegese tælles også studier over Jobs Bog, Jeremias' Bog og de sene historiske bøger. ${ }^{22}$

Mowinckels fokus på kulten som det vigtigste omdrejningspunkt for de gamle israelitters oplevelse af virkeligheden repræsenterer ligesom Pedersens tolkning - som Mowinckel også er inspireret af - et forsøg på at forstå de gammeltestamentlige teksters univers indefra. Stort set ingen abonnerer i dag på tesen om Jahves tronbestigelsesfest. ${ }^{23}$ I studiet af Salmernes Bog er der igen kommet langt større vægt på det litterære perspektiv ved teksterne. Således mener de fleste i dag, at teksterne ikke er direkte produkter af en historisk kultisk praksis men snarere reflekterer og refererer til denne på mere subtile måder netop i deres egenskab af litterære produkter. ${ }^{24}$

19. Mowinckel, Psalmenstudien III. Kultprophetie und prophetische Psalmen, Videnskabsselskapets Skrifter. II. Hist.-filos. Klasse 1922. No. 1 (Kristiania: In Kommission bei Jacob Dybwad 1923).

20. Sigmund Mowinckel, Le décalogue, Études d'histoire et de philosophie religieuses publiées par la Faculté de Théologie protestante de l'Université de Strasbourg 16 (Paris: Libraire Félix Alcan 1927).

21. Sigmund Mowinckel, Profeten Jesaja. En bibelstudiebok (Oslo: Aschehoug \& co. 1925); Jesaja-Disiplene. Profetien fra Jesaja til Jeremia (Oslo: Aschehoug \& co. 1926). 22. Sigmund Mowinckel, Zur Komposition des Buches Jeremia, Videnskabsselskapets Skrifter. II. Hist-filos. Klasse 1913. No. 5 (Kristiania: In Kommission bei Jacob Dybwad 1914); Diktet om Ijöb og hans tre venner (Kristiania: Aschehoug \& co. 1924); Ezra den skriftlarde. Studier til den jødiske Menighets Historie og Litteratur, Anden Samling (Kristiania: Olaf Norlis Forlag 1916); Studien zu dem Buche EzraNehemia 1-3 (Oslo: Universitetsforlaget 1964). I fortolkningen af Mosebøgerne holdt han fast i kildesondringen, ganske vist i en revideret version i forhold til den klassiske Wellhausen-model. Se Mowinckel, Erwägungen zur Pentateuch-Quellenfrage (Oslo: Universitetsforlaget 1964); Mowinckel, Tetrateuch - Pentateuch - Hexateuch. Die Berichte über die Landnambe in den drei altisraelitischen Geschichtswerken, BZAW 90 (Berlin: Alfred Töpelmann 1964).

23. Mowinckel er da også blevet kritiseret for at bygge en meget omfattende tese på et temmelig spinkelt tekstligt grundlag - nogle har ligefrem kaldt tesen om tronbestigelsesfesten for en "omvendt pyramide". Jf. Knight (2016), $25 f$.

24. For en nyere dansk revurdering af forholdet imellem kulten og salmerne, se Pernille Carstens: "Mellem tavshed og sang. Hvad er der blevet af den kultiske tolkning af de gammeltestamentlige salmer?” DTT 64 (2001), 97-110. 


\section{Den komparative religionshistorie}

Mowinckel gjorde i sin kultiske tolkning af de gammeltestamentlige salmer i stor udstrækning brug af det babyloniske materiale - klagesalmer og beskrivelser af akitu-festen. I Sverige havde Johannes Lindblom (1882-1974) fra begyndelsen af 1920rne kastet sig over studiet af de gammeltestamentlige profettekster med afsæt i en komparativ religionsfænomenologisk orienteret tilgang. Lindblom, der 1909 blev docent i Uppsala, var professor ved Åbo Akademi 1924-1930 og ved universitetet i Lund 1930-1947. Hans bog Die literararische Gattung der prophetischen Literatur, der kom i 1924, var bemærkelsesværdig ved at inddrage middelalderens mystikere, ikke mindst Birgitta af Vadstena, som en analogi til profeterne i Det Gamle Testamente. ${ }^{25}$ Forståelsen af profetteksterne som visions- eller åbenbaringsberetninger var ifølge Lindblom en nøgle til at se meningen med de bratte brud, stemningsomslag, vekslen imellem stemmer og adressater, der optræder i profetteksterne. Forskningens forsøg på at inddele de gammeltestamentlige profetskrifter i skarpt adskilte undergenrer (orakel, anklage- eller formaningstale, veråb, forbandelse osv.) går fejl af deres basale karakter af åbenbaringslitteratur. Lindbloms arbejde med profetlitteraturen og den profetiske erfaring med inddragelse af et stort komparativt materiale fra religionshistorien udgjorde et vægtigt skandinavisk bidrag til den gammeltestamentlige forskning. ${ }^{26}$

Lindbloms forankring af det gammeltestamentlige studium i den sammenlignende religionsvidenskab kommer før opdagelsen og offentliggørelsen af Ras Shamra-arkivet. Teksterne herfra spiller til gengæld en afgørende rolle for et andet arbejde med en komparativ synsvinkel, nemlig Flemming Hvidbergs Graad og Latter i Det Gamle Testamente, der udkom i 1938 og handler om den nærorientalske forestilling om en døende og opstående guddom. ${ }^{27}$ Primært med udgangspunkt i Ras Shamra-teksterne rekonstruerer Hvidberg en kanaanæisk frugtbarheds- og seksualkult, som han mener har sat

25. Johannes Lindblom, Die Literarische Gattung der prophetischen Literatur. Eine literargeschichtiche Untersuchung zum Alten Testament, UUÅ 1924. Teologi. 1 (A.B. Lundequistska Bokhandeln 1924).

26. Johannes Lindblom, Hosea literarisch untersucht, Acta Academiae Aboensis. Humaniora V (Åbo: Åbo Akademi 1927); Profetismen i Israel (Stockholm: Svenska Kyrkans Diakonistyrelses Bokförlag 1934); Den gammaltestamentliga religionens egenart. En metodologisk och exegetisk studie, Lunds Universitets Årsskrift N. F. Avd. 1. Bd. 31. Nr. 1 (Lund: C. W. K. Gleerup 1935).

27. Flemming Hvidberg, Graad og Latter i Det gamle Testamente. En Studie i kanaan๔isk-israelitisk Religion, Festskrift udgivet af Københavns Universitet i Anledning af Universitetets Aarsfest November 1938 (København: Bianco Lunos Bogtrykkeri 1938). 
sig væsentlige spor også i Det Gamle Testamente: Gråden og latteren repræsenterer således den kultiske klage over guddommens død og den orgiastisk prægede glæde over hans genkomst. Hvidberg, der var docent fra 1929 og fra 1941 professor ved Københavns universitet, har ikke noget omfattende forfatterskab; men hans medrivende og veloplagte stil har givetvis også åbnet manges øjne for det fascinerende ved den gammeltestamentlige verden.

\section{Det sakrale kongedømme}

Ras Shamra-teksterne er ligeledes vigtige for den svenske gammeltestamentler Ivan Engnells Studies in Divine Kingship in the Ancient Near East fra 1943. ${ }^{28}$ Engnell, der blev professor i Uppsala 1947, betoner kongefigurens centrale betydning i Det Gamle Testamente og i nærorientalsk religion generelt. Bogen var tænkt som et første bind, der skulle følges af en mere indgående behandling af det tilsvarende stof i Det Gamle Testamente, som dog aldrig udkom. Synspunkterne blev videreført på selvstændig vis af religionshistorikeren Geo Widengren (1907-1996), hvis bog The King and the Tree of Life in Ancient Near Eastern Religion fra 1951 ligeledes understregede det sakrale kongedømme i Det Gamle Testamente. Kongen blev set som inkarnationen af den døende og opstående guddom; og en række gammeltestamentlige tekster, ikke mindst fra Salmernes Bog, blev læst som beskrivelser af den lidelse, kongen gennemgik som hovedperson i kultens rituelle drama. ${ }^{29}$

Forestillingen om kongen som en guddommelig figur i det gamle Israel og om kongens centrale plads i kult og bevidsthed blev taget op af en lang række forskere i og uden for Norden med forskellige betoninger. En selvstændig position indtog Mowinckel, der bl.a. i sin bog om de messianske forestillingers historie argumenterede for, at den jødiske Messias-ide har sin oprindelse i den israelitiske udgave af en nærorientalsk kongeidelogi, som dog længe forblev rent dennesidig og først gradvis omformedes i eskatologisk og transcendent retning. ${ }^{30}$ Aage Bentzen (1894-1953), der i 1929 overtog professoratet i Det Gamle Testamente i København efter I. C. Jacobsen, havde sin

28. Ivan Engnell, Studies in Divine Kingship in the Ancient Near East (Uppsala: Almqvist \& Wiksells Boktryckeri 1943).

29. Geo Widengren, The King and the Tree of Life in Ancient Near Eastern Religion, UUÅ 4 (Uppsala: A.B. Lundequistska Bokhandeln 1951).

30. Sigmund Mowinckel, Han som kommer. Messiasforventningen i Det gamle testament og på Jesu tid (København: G.E.C. Gad 1951). 
egen position: Han var stærkt inspireret af Engnells og Widengrens synspunkter, men nuancerede dem også. Som noget væsentligt pegede Bentzen på, at der bag kongemotivet lå en mere overordnet og universel "urmenneske"-forestilling. ${ }^{31}$

Tanken om den allestedsnærværende kongeideologi har senere generationer af eksegeter afskrevet som ensidig. I sin samtidige kontekst repræsenterede den imidlertid et forsøg på at gøre komparative religionsstudier frugtbare for forståelsen af Det Gamle Testamente. Den markante - og på mange måder overdrevne - understregning af kongefigurens betydning banede samtidig vej for en fornyet opmærksomhed på Messias-forestillingers betydning i den antikke jødedom og dermed indirekte på sammenhænge imellem de gammelog nytestamentlige universer.

Generelt fandt den teologiske genbesindelse på Det Gamle Testamentes plads i kanon, som prægede den tyske debat i mellem- og efterkrigsårene, ikke den store genklang blandt skandinaviske eksegeter. Aage Bentzen er formentlig den forsker i denne generation, der mest udførligt har behandlet spørgsmålet om Det Gamle Testamentes stilling inden for den kristne kirkes sammenhæng. ${ }^{32}$ Bentzen understreger dialektikken i den kristne reception af Det Gamle Testamente; man kan - som i ortodoksien - betone ligheden imellem det Gamle og det Nye Testamente for stærkt på den historiske forskelligheds bekostning. Men man kan også gå for vidt $\mathrm{i}$ at fokusere på det helt nye ved Kristi budskab, så man glemmer de mange berøringspunkter med den gammeltestamentlige tradition. Bentzen vil knytte Det Gamle Testamentes teologiske relevans sammen med dets "fremmedhed" i forhold til kristendommen: Den første del af kanon åbner et vindue til et andet og fremmedreligiøst univers. I denne forstand repræsenterer Det Gamle Testamente i forhold til kristendommen noget radikalt "andet"; men samtidig er Det Gamle Testamente historisk knyttet så tæt sammen med kristendommen, at det kan danne afsæt for en dybere og mere kongenial forståelse af ikke-kristen religiøsitet (Bentzen 1929, 52).

31. Aage Bentzen, Det sakrale kongedømme. Bemarkninger i en løbende diskussion om de gammeltestamentlige salmer. Festskrift udgivet af Københavns Universitet i anledning af Universitetets aarsfest november 1945 (København: Bianco Lunos Bogrtykkeri 1945).

32. Se Aage Bentzen, Det gamle Testamente. Tre Foredrag (København: P. Haase \& Søns Forlag 1929). Bentzens position er behandlet mere udførligt i Høgenhaven (2016). 


\section{Traditionshistorien i skandinavisk udgave}

Som allerede nævnt indebar i Johannes Pedersens arbejde en udtrykkelig polemisk front mod den traditionelle kildekritik. Opgøret med kildekritikkens dominans blev navnlig i tiden efter Anden Verdenskrig til et centralt tema for flere skandinaviske forskere. I sin skandinaviske udgave blev traditionshistorien således til et egentligt brud med kildekritikken. ${ }^{33}$ Et foregangsarbejde var her H.S. Nybergs (1889-1974) undersøgelse af Hoseas' Bog (1935): Nyberg lagde her i langt højere grad, end det ellers havde været gængs, vægt på betydningen af den mundtlige tradition for tilblivelsen af den gammeltestamentlige profetlitteratur. ${ }^{34}$ En lignende synsmåde med vægt på mundtlighedens betydning for profetlitteraturen i Det Gamle Testamente slog nordmanden Harris Birkeland (1904-1961) til lyd for. ${ }^{35}$

Ivan Engnell fremlagde sit syn på den gammeltestamentlige litteraturs mundtlighed som det afgørende kendetegn i sin indledning til Det Gamle Testamente fra 1945. Bogen er for så vidt en torso, som den anden del, der var planlagt til at skulle følge efter, aldrig så dagens lys. ${ }^{36}$ I den foreliggende første del argumenterer Engnell med stor energi for, at litterærkritikken og den evolutionisme, som den er forbundet med, er udtryk for en moderne europæisk miskendelse af den antikke nærorientalske litteratur, som vi finder i Det Gamle Testamente. Sine synspunkter på Det Gamle Testamentes litterære genrer og deres tilblivelse fremlagde Engnell desuden i en række artikler, heraf mange i Svensk Bibelsk Uppslagsverk. ${ }^{37}$

Den traditionshistoriske linje blev i Danmark ganske særlig taget op af Eduard Nielsen (f. 1923), der var professor i København 19561991. Hans Oral Tradition fra 1954, der bygger på en række artikler trykt i Dansk Teologisk Tidsskrift, er et forsvar for det traditionshisto-

33. Se hertil Eduard Nielsen, "The Traditio-Historical Study of the Pentateuch since 1945, with Special Emphasis on Scandinavia”, Law, History, and Tradition: Selected Essays by Eduard Nielsen Issued by friends and colleagues (København: G.E.C. Gad 1983), 138-154; også i The Productions of Time: Tradition History in Old Testament Scholarship, a Symposium at Sandbjerg Manor, Denmark, May 1982, red. Knud Jeppesen \& Benedikt Otzen (Sheffield: Almond Press 1984), 11-28.

34. H. S. Nyberg, Studien zum Hoseabuche. Zugleich ein Beitrag zur Klärung des Problems der alttestamentlichen Textkritik, UUÅ 1935:6 (Uppsala: A.B. Lundsqvistska Bokhandeln 1936).

35. Harris Birkeland, Zum hebräischen Traditionswesen: Die Komposition der prophetischen Bücher des Alten Testaments, Avhandlinger utgitt av det norske videnskabsakademi i Oslo 1938 (Oslo: In Kommission bei Jacob Dybwad 1938).

36. Ivan Engnell, Gamla testamentet. En traditionshistorisk inledning I (Stockholm: Svenska Kyrkans Bokförlag 1945).

37. Ivan Engnell \& Anton Fridrichsen (red.), Svenskt Biblisk Uppslagsverk I-II (Gävle: Skolförlaget 1948-1952). 
riske perspektiv på Det Gamle Testamente i den skandinaviske udgave..$^{38}$ Nielsen gør her udtrykkeligt opmærksom på, at traditionshistorikeren ikke kan bygge videre på litterærkritikkens arbejde. Dertil er de metodiske tilgange ganske enkelt for forskellige:

Han [traditionshistorikeren] kan netop ikke uden videre fortsætte litterærkritikerens arbejde. Hvor meget end deres intention er den samme, er deres metoder dog for forskellige. Først og fremmest fordi traditionshistorikeren bevidst har gjort op med de kulturelle forudsætninger, der hører baade litterærkritikerens og hans egen tid til (Nielsen 1952, 129. Jf. Nielsen, Oral Tradition, 64).

Hermed lægger Nielsen sig på same linje som Engnell, der ligeledes understreger den traditionshistoriske metodes karakter af et nyt perspektiv, der ikke vil supplere men erstatte litterærkritikken. Nielsen gør i denne sammenhæng udtrykkeligt opmærksom på, at traditionshistorien ikke i udgangspunktet kan betegnes som mere eller mindre konservativ eller kritisk over for den tradition, som er indeholdt i Det Gamle Testamente. I praksis udviser traditionshistorien dog langt større respekt for traditionen i den forstand, at man her tiltror skaberne af de gammeltestamentlige tekster en langt større evne til - med Nielsens udtryk - "andet og mere end redaktionel klodsethed" (Nielsen 1952, 129). På konkrete punkter kan traditionshistorikeren sagtens være enig med litterærkritikeren; men den grundlæggende metode er en anden. Nielsen nævner som et eksempel det bevidst etablerede kronologiske skema i Første til Fjerde Mosebog, et lag i teksterne, der kan identificeres med litterærkritikkens P-kilde. I traditionshistoriens optik ikke er P dog ingen uafhængig kilde; og det giver heller ikke mening at opfatte $P$ som en mekanisk arbejdende "redaktor", som primært sammenstiller og harmonisere traditioner, andre har skabt. P-laget repræsenterer derimod stor forfatterkunst i omgangen med en foreliggende tradition.

Den skandinaviske forståelse af traditionshistorie adskiller sig på væsentlige punkter fra den form for traditionshistorie, som blev fremherskende blandt tyske eksegeter fra mellemkrigsårene og frem. De tyske traditionshistorikere ville spore overleveringer, der gik tilbage til tiden før den gammeltestamentlige litteratur blev skriftlig fikseret. De fastholdt i det væsentlige kildekritikkens resultater og dateringen

38. Eduard Nielsen, Oral Tradition: a Modern Problem in Old Testament Introduction, Studies in Biblical Theology 11 (London: SCM Press 1954). Jf. Eduard Nielsen, "Mundtlig tradition. I. Til orientering i et aktuelt indledningsproblem", DTT 15 (1952), 19-37; "Mundtlig tradition. II. 'Når din søn spørger dig i morgen, da skal du sige...”, DTT 15 (1952), 88-106; "Mundtlig tradition. III. Et par traditionshistoriske analyser”, DTT 15 (1952), 129-146. 
af de ældste "kilder" i Mosebøgerne - Jahvisten og Elohisten - til den tidlige kongetid. Traditionshistorien blev en metode til at komme et skridt længere tilbage - til dommertiden og tiden for israelitternes indvandring i Kanaan. For de skandinaviske traditionshistorikere derimod trådte traditionshistorien i stedet for litterærkritikken. Opmærksomheden på den mundtlige overlevering leverede ikke nogen nøgle til at komme bag om den litterære tradition i historisk forstand men var snarere et middel til en bedre og mere nuanceret forståelse af teksterne. Når tidlige og sene elementer kunne optræde side om side i teksterne, kunne disse elementer set med skandinaviske øjne ikke være sikre kriterier for datering af tekster eller særlige "lag". De nordiske traditionshistorikere forestillede sig i praksis gerne, at den litterære fiksering var sket på et sent tidspunkt og indbefattede mængder af ældre stof uden, at dette med nogen form for vished kunne skilles ud.

\section{Fællesnævnere for den skandinaviske gammeltestamentlige eksegese?}

Der er ingen tvivl om, at første halvdel af det 20. århundrede var en overordentlig frugtbar periode for den gammeltestamentlige forskning i Skandinavien. De impulser, der udgår herfra, kan ikke bringes på enkle, samlende formler. Der var, som vi har set, betragtelige forskelle imellem de enkelte eksegeter. Mowinckel holdt således fast i kildesondringen, ganske vist i sin egen version, ligesom han trods al anerkendelse også var kritisk i forhold til Engnells og Widengrens betoning af det sakrale kongedømme. Bentzen stod, hvad angår synet på Mosebøgerne, i det væsentlige for en fortsættelse af Buhls og Jacobsens linje med tilslutning til kildekritikken i dens klassiske udgave, hvorimod han på salmeforskningens område tydeligt var påvirket af Mowinckels kultiske tolkning, som han også videreudviklede bl.a. under indflydelse af den svenske forskning i det sakrale kongedømme.

Ikke desto mindre lader det sig gøre at indkredse nogle fællesnævnere, der kan siges at kendetegne den skandinaviske forskning i Det Gamle Testamente i tiden 1900-1950. Den stærke interesse for den gammeltestamentlige forestillingsverdens radikale fortidighed og fremmedhed i forhold til moderne europæisk mentalitet og kultur, det eksotiske eller "anderledesheden" ved de gammeltestamentlige tekster og den verden, de afspejler, er et karakteristisk træk ved de betydelige skandinaviske eksegeter i denne tid. Kendetegnende for deres tilgang er mere konkret den kultiske interesse, det religionshi- 
storiske komparative perspektiv og endelig vægten på traditionshistorien og mundtlighedens betydning.

Der kan være gode grunde til at spørge, hvordan den nyorientering, som tegner sig inden for det gammeltestamentlige forskningsfelt særlig i perioden 1920-1950 kan anskues i sammenhæng med tidens kulturhistoriske strømninger i det hele taget. Det er selvfølgelig vigtigt at holde sig for øje, at der er nogle faginterne forhold på færde, ikke mindst opdagelsen af Ras Shamra-arkivet og disse teksters offentliggørelse fra 1929 og frem. Pedersens og Mowinckels banebrydende arbejder ligger imidlertid i tiden inden Ras Shamra-testernes fremkomst. Og der er formentlig ikke tvivl om, at virkningen af deres indsats blev forstærket af og i et eller andet vanskelig definerbart omfang også var betinget af tendenser i tiden: Oven på Første Verdenskrigs katastrofer og de samfundsomstyrtninger, der fulgte i krigens kølvand, var der generelt mindre opbakning bag en optimistisk tro på udvikling og fremskridt, der satte den moderne europæiske kultur højest på en objektiv rangstige eller som slutpunktet på en kulturhistorisk evolution. Derimod kaldte tiden på en fornyet interesse for fremmede eksotiske kulturer fra fortid og nutid. Deres udtryk kom på en ny måde til at fremstå som relevante alternativer til nutidens problematiske selvforståelse. Det gammeltestamentlige verdenssyn, som det fremstod i Pedersens og Mowinckels medrivende tolkninger, kunne - også - ses i dette lys. Det Gamle Testamente var mao blevet relevant netop i sin fremmedhed og "primitivitet". Hvad der havde forekommet tidligere generationer frastødende eller i det mindste problematiske rester af for længst overvundne religiøse stadier, virkede nu på baggrund af en måske nok lidt diffus vitalistisk optik netop som attraktive glimt af en særligt gammeltestamentlig sans for det jordiske liv og for den ekstatiske kult som en længselsfuldt anet enhed imellem jordisk og evigt.

De skandinaviske eksegeter leverede ikke i samme grad som deres tyske kolleger i samme periode direkte bidrag til den gammeltestamentlige teologi eller den hermeneutiske refleksion over Det Gamle Testamentes status og betydning i den kristne teologis sammenhæng. Men deres genopdagelse af de gammelteksters egenartede univers og af det fremmede i det tilsyneladende fortrolige kom på samtidens aktuelle baggrund til at tale for Det Gamle Testamentes nutidige relevans. 